\title{
Effect of zero-valent iron nanoparticles on the phytoextraction ability of Kochia scoparia and its response in $\mathrm{Pb}$ contaminated soil
}

\author{
Ali Daryabeigi Zand ${ }^{1^{\dagger}}$, Alireza Mikaeili Tabrizi ${ }^{2}$ \\ ${ }^{1}$ School of Environment, College of Engineering, University of Tehran, No. 25, Azin St., 141556135 Tehran, Iran \\ ${ }^{2}$ Department of Environmental Sciences, Gorgan University of Agricultural Sciences \& Natural Resources, Shahid Beheshti St.,4913815739 Golestan, Iran
}

\begin{abstract}
Nanotechnology-supported phytoremediation is a new approach in remediation of toxic metal polluted soils, but very little is known about the effects of nanoparticles on plant survival and performance in Pb-contaminated soil. Seedlings of $K$. scoparia were exposed to different regimes of nanoparticles of zero-valent iron (nZVI) to investigate nZVI effects on plant growth, $\mathrm{Pb}$ uptake and accumulation and physiological response. Results indicated that the total $\mathrm{Pb}$ contents in K. scoparia treated with low to moderate concentrations of $\mathrm{nZVI}(100-500 \mathrm{mg} / \mathrm{kg})$ were higher than those in control, with the highest $\mathrm{Pb}$ accumulation capacity of $857.18 \mu \mathrm{g}$ per pot obtained in soil treated with $500 \mathrm{mg} / \mathrm{kg}$ nZVI. Translocation of $\mathrm{Pb}$ from the roots to the shoots of $K$. scoparia slightly increased with nZVI content of soil from 100 to $500 \mathrm{mg} / \mathrm{kg}$, while $\mathrm{Pb}$ transfer in $\mathrm{K}$. scoparia was suppressed at higher nZVI doses. This might be related to the biomass reduction and decrease of chlorophyll content induced by high nZVI levels. Results provide a promising method to remediate Pb-polluted soil by applying proper amounts of nZVI to enhance phytoremediation performance. Selective interaction of plants and nZVI has great application prospects in the context of soil remediation.
\end{abstract}

Keywords: K. scoparia, lead, phytoremediation, soil, zero-valent iron nanoparticles

\section{Introduction}

Soil is a major sink for heavy metals released into the environment. Heavy metals in different media e.g. in soil can find their way into human bodies and exert toxic effects on human health. Over the past decades, rapid growth of population, increasing agricultural activities, waste disposal, mining and industrialization caused extensive soil contamination throughout the world [1, 2]. Heavy metals are persistent in nature and mainly do not undergo microbial degradation, therefore might be uptaken by living organisms and accumulated in their tissues. Accumulation of non-biodegradable heavy metals e.g. $\mathrm{Cr}, \mathrm{Pb}, \mathrm{Cd}, \mathrm{Ad}, \mathrm{Ni}$, and $\mathrm{Hg}$ in human body may pose serious health problems [3]. However, toxicity of heavy metals depends on various factors such as the dose of absorbed metal as well as the route and duration of the exposure [4]. Lead $(\mathrm{Pb})$ is among the most common heavy metals found in contaminated sites [5]. Based on the Agency for Toxic Substances and Disease Registry, lead $(\mathrm{Pb})$ has been ranked $2^{\text {nd }}$ among the top 10 hazardous substances. Pb mainly occurs in two different oxidation states (II and IV), but the divalent lead, $\mathrm{Pb}(\mathrm{II})$, is the most prevalent and stable form of this toxic contaminant in the natural environment [6]. In addition to humans and animals, $\mathrm{Pb}(\mathrm{II})$ is a toxic heavy metal for plants causing morphological, physiological, and biochemical dysfunctions in plant species. Lead, at certain levels, may interfere with plant establishment and growth, nutrient uptake and photosynthesis. Ascending trend of catalase and peroxidase activities in $\mathrm{Pb}$-stressed plants at lower $\mathrm{Pb}$ concentrations in soil followed by declining trend at higher $\mathrm{Pb}$ levels has been reported [7]. Environmental contamination of $\mathrm{Pb}(\mathrm{II})$ is gaining growing attention worldwide because of its high levels and frequent occurrence in soil and water.

Indeed, the remediation of $\mathrm{Pb}$-contaminated soils brings a techno-economical challenge for researchers and decision makers. Several physical, chemical and biological approaches have been
This is an Open Access article distributed under the terms of the Creative Commons Attribution Non-Commercial License (http://creativecommons.org/licenses/by-nc/3.0/) which permits unrestricted non-commercial use, distribution, and reproduction in any medium, provided the original work is properly cited.

Copyright (C) 2021 Korean Society of Environmental Engineers
Received May 11, 2020 Accepted July 30, 2020

${ }^{\dagger}$ Corresponding author

Email: adzand@ut.ac.ir

Tel: +98-21-61113154

ORCID: 0000-0002-2490-0893 
employed to remove heavy metals such as lead from soil such as soil flushing, soil washing and bioremediation. Among the various remediation technologies, phytoremediation is one of the most promising, ecologically friendly, and economical remediation approaches, which can uptake heavy metals and eliminate the contaminants from soil [8]. Phytoremediation, which is also known as enhanced bioremediation, has attracted remarkable attention, especially in recent decade. Phytoremediation is a faster cleanup process compared to bioremediation. Bioremediation only uses naturally occurring or introduced microorganisms to degrade or remove contaminants in soil, whereas phytoremediation employs both plants and their associated microbes to remediate soil polluted with a wide range of contaminants such as toxic metals, organics, and radionuclides. Phytoremediation is known to be a more rapid remediation technique compared to bioremediation [9]. Introduction of plant species to a contaminated site provides an opportunity to yield several indirect contaminant attenuation mechanisms. Such mechanisms can promote the removal of toxic metals from soil. However, contaminant removal mechanisms involved in phytoremediation are complex and not limited only to the direct metabolism of contaminants by plants [10]. Certain indirect attenuation mechanisms are also involved in phytoremediation, such as the metabolism of contaminants by plant-associated microbes in the rhizosphere and/or plant-induced modifications in the contaminated environment. In terrestrial species, transport of contaminants towards the plant is dominated by the uptake of water by roots, and distribution within the plant mainly relies on xylem or phloem transport [11]. Plants can uptake contaminants like heavy metals from soil and transfer them to the harvestable parts through a sub-process called phytoextraction. This process often occurs with heavy metals, radionuclides and certain organic compounds that are resistant to plant metabolism. Phytoextraction of heavy metals was reported to be ten times more economical compared to conventional remediation techniques [12]. Selected plants for phytoextraction should have rapid growth, extended root system, and high biomass production [13]. Reduction in mobility of heavy metals in soil occurs through phytostabilization. Contaminants can be immobilized from soil or sediment onto plant root surfaces, or precipitated within the plant rhizosphere [14]. Phytoremediation of $\mathrm{Pb}$ using L. perenne in soil contaminated with $\mathrm{Pb}$ (up to $21 \mathrm{~g} / \mathrm{kg}$ ) showed accumulation of ca. $1.5 \mathrm{~g} / \mathrm{kg} \mathrm{Pb}$ in plant tissue after four months [15]. In a study by Saghi et al. [16], 100 to $500 \mathrm{mg} / \mathrm{kg} \mathrm{Pb}$ were applied to soil, and it was found that growth parameters of $R$. rugosum and $S$. arvensis did not decrease significantly. In addition, higher accumulation of $\mathrm{Pb}$ in roots of the studied plant species was observed compared to shoots. Phytoremediation is a solar-driven remediation approach with no destructive impact on soil fertility. This technology is socially and aesthetically compelling since it can be easily incorporated into landscape design. There is also a possibility to combine phytoremediation with other techniques to enhance its effectiveness [5, 8, 11].

The use of nZVI as a feasible and prospective strategy to remediate heavy metals-polluted soils has been suggested by several researchers [16, 17]. Immobilization of heavy metals in soil through applying nZVI has been found to be a principal mechanism by which remediation goals at metal-contaminated sites can be achieved. However, the effectiveness of nZVI to immobilize metals in soils depends on various factors, such as soil properties, dose of applied nZVI, and presence of non-target pollutants. Immobilization of anionic heavy metals (As and $\mathrm{Cr}$ ) were greater in acidic soils, while retention of cationic heavy metals $(\mathrm{Pb}, \mathrm{Cd}$ and $\mathrm{Zn}$ ) were found to be higher in calcareous soil. Immobilization of $\mathrm{Pb}$, As and $\mathrm{Cr}$ increased more than $82 \%$ through application of $10 \%$ of nZVI; however, nZVI could not significantly affect immobilization of Cd (only 13\% to 42\%), regardless of the soil $\mathrm{pH}$ [16, 17].

Nanotechnology-assisted phytoremediation is a novel approach for remediation of contaminated soil, sediment, and water. To date, application of nZVI in planted soils has mostly limited to plant stresses caused by these nanoparticles [18-20], and information on promoted remediation of contaminated soils under the combined effect of plants and nZVI is still scant. Enhanced growth of plants was observed at lower levels of applied nZVI, while higher rates of nZVI caused nanotoxicity [21]. Indeed, application of high levels of some nanomaterials for remediation purposes has raised concerns, due to their ambiguous fate in the environment and probable toxic effects on living organisms, particularly on plants; however, contradictory results have been reported in the literature. Inhibitory effects of above $500 \mathrm{mg} / \mathrm{kg} \mathrm{nZVI} \mathrm{on}$ rice seedlings was reported [22], while application of $500 \mathrm{mg} / \mathrm{L}$ nZVI promoted root growth for $A$. thaliana [23]. Enhanced activity of soil enzyme and reduced microbial toxicity was also reported in heavy metals-contaminated soil remediated with 1\% nZVI [24]. Wang et al. [26] found suppressed uptake of Cr by Chinese cabbage and edible rape in soil amended with nZVI. To the best of our knowledge, integration of zero-valent iron nanoparticles with phytoremediation process has rarely been investigated to remove $\mathrm{Pb}$ from soil, which was addressed in this research.

The main aim of this study was to investigate the remediation of Pb-polluted soil through nZVI-assisted phytoremediation. We specifically studied: (i) the effect of nZVI treatments on the biomass and length of plants and their photosynthetic chlorophyll content; (ii) uptake and translocation of $\mathrm{Pb}(\mathrm{II})$ in $K$. scoparia grown in nZVI-treated soil; and (iii) impact of nZVI on accumulation capacity and remediation potential of $K$. scoparia to eliminate $\mathrm{Pb}(\mathrm{II})$. This research could illustrate the possible pros and cones of integrated application of nZVI and phytoremediation process in removal of $\mathrm{Pb}(\mathrm{II})$ from soil.

\section{Material and Methods}

\subsection{Soil Preparation and Analysis}

The soil was collected from a depth of 0-30 cm from a non-metal-contaminated area in Southern part of Tehran Province, Iran $\left(35^{\circ} 32 \mathrm{~N}\right.$, $51^{\circ} 24^{\prime} \mathrm{E}$ ). The collected soil samples were sieved through a $2-\mathrm{mm}$ mesh to exclude the gravel and large debris, and then air-dried $\left(22-25^{\circ} \mathrm{C}\right)$ for one week. The sieved soil was thoroughly mixed by hand before adding $\mathrm{Pb}$ to soil. The obtained soil was placed in plastic pots. Each pot filled with $1 \mathrm{~kg}$ of soil mixed with 150 $\mathrm{mL}$ distilled water (DW) containing dissolved salt of $\mathrm{Pb}\left(\mathrm{NO}_{3}\right)_{2}$, to provide desired level of $\mathrm{Pb}$ in soil $(20 \mathrm{mg} / \mathrm{kg})$. In the control 
pots $150 \mathrm{~mL}$ of clean DW was added [25]. The pots were kept in a dark room $\left(20-24^{\circ} \mathrm{C}\right)$ and incubated for eight weeks at $75 \%$ of field capacity using tap water before planting. Chemical analysis of the pots soil was carried out prior to sowing the seeds. Briefly, the soil $\mathrm{pH}$ was measured in suspension using a 1:2.5 (w/v) ratio of soil-water ratio. Phosphorus was determined by Olsen $\mathrm{P}$ extracting solution (0.5 M NaHCO3, pH 8.5), total nitrogen by the Kjeldahl measurement (VELP Scientifica, UDK 142, Italy). Electrical conductivity (EC) was measured using a conductivity meter in a soil-water extract (1:2.5 soil: water ratio (w/v)) [26, 27]. Organic carbon (OC) content was measured according to the Walkley-Black method, in which organic carbon is oxidized using potassium dichromate [28]. The soil texture was determined using a Bouyoucos densitometer which is classified as Clay-Loam (CL). Selected characteristics of the used soil are given in Table S1. The obtained data represent the mean value of three replicates. The electrical conductivity of the used soil was $2.15 \mathrm{dS} / \mathrm{m}$ (Table S1). High values of soil electrical conductivity i.e. greater than $4 \mathrm{dS} / \mathrm{m}$ may adversely affect plant growth regardless of soil contamination type and level [29]. The total concentrations of metals in soil samples were determined through acid digestion with a mixture of $6 \mathrm{~mL}$ nitric acid and $2 \mathrm{~mL}$ chlorhydric acid in a microwave reaction system. Obtained extract was then analyzed for metals concentrations using an atomic absorption spectrophotometry (Perkin Elmer 700) according to the standard methods. All the analytical determinations were carried out in triplicate and the mean values were reported [16].

\subsection{Preparation of $n Z \mathrm{VI}$}

Nanoscale zero-valent iron (nZVI) was selected to be used in this study because of its high specific surface area and strong reducibility. It is also pretty simpler than some other nanomaterials to be prepared and the low cost makes it an attractive nanomaterial for remediation purposes. Moreover, nZVI has been reported to pose less toxicity for the plants [16, 17, 19]. Zero-valent iron nanoparticles were prepared using borohydride reduction method. $\mathrm{FeSO}_{4} .7 \mathrm{H}_{2} \mathrm{O}(4 \mathrm{~g})$ was dissolved in $200 \mathrm{~mL}$ of methanol/deionized water (30\%:70\% (v/v)). The $\mathrm{pH}$ was adjusted to 6.8 using $3.8 \mathrm{M}$ $\mathrm{NaOH}$. The $\mathrm{NaBH}_{4}$ (1.5 g) powder was dissolved in $10 \mathrm{~mL}$ of de- ionized water and added dropwise to the prepared mixture in ultrasonic shaker at $25^{\circ} \mathrm{C}$ for $45 \mathrm{~min}$. The mixture was then stirred thoroughly at $250 \mathrm{rpm}$ for another $45 \mathrm{~min}$. The obtained particles were then centrifuged at 5,000 rpm for $15 \mathrm{~min}$, washed at least three times with methanol, filtered, dried under vacuum condition for $6 \mathrm{~h}$ and pulverized. The ferrous iron was reduced to zero-valent iron based on the following equation [30]:

$$
\mathrm{Fe}\left(\mathrm{H}_{2} \mathrm{O}\right)_{6}{ }^{3+}+3 \mathrm{BH}_{4^{-}}+3 \mathrm{H}_{2} \mathrm{O} \rightarrow \mathrm{Fe} \downarrow+3 \mathrm{~B}(\mathrm{OH})_{3}+10.5 \mathrm{H}_{2}(1)
$$

The prepared nZVI nanoparticles were immediately suspended in deionized water into tightly dark, stoppered bottles at room temperature. Then, the volume of the suspension was made up to $100 \mathrm{~mL}$ with deionized water, containing the desired concentration of the nZVI per $100 \mathrm{~mL}$ deionized water. The size of nZVI were determined using transmission electron microscopy (TEM), manufactured by PHILIPS (EM208 S), with an acceleration voltage of $100 \mathrm{kV}$. Selected TEM images of the synthesized nZVI are shown in Fig. 1. The size of the nZVI particles covers a range between 40 and $100 \mathrm{~nm}$. Selection of nZVI concentration range was based on the preliminary experiments, which showed that nZVI concentration of lower than $100 \mathrm{mg} / \mathrm{kg}$ had negligible influence on plant growth and metal uptake. Applying higher than 1,500 mg/kg nZVI to soil exhibited severe inhibitory effects on plant growth. Therefore, the nZVI concentration range was selected as $100-1,500 \mathrm{mg} / \mathrm{kg}$ to assess the impacts of nZVI on phytoremediation of Pb-contaminated soil.

\subsection{Pot Experiment}

Plant seeds were obtained from the National Plant Gene Bank of Iran (NPGB) and sown in plastic pots containing different concentrations of nZVI. Nanoparticles of ZVI at doses of 0, 100, 300, $500,1,000$ and $1,500 \mathrm{mg} / \mathrm{kg}$ were added to the prepared plastic pots containing $\mathrm{Pb}$-contaminated soil and thoroughly mixed. $K$ scoparia was cultivated over a $60 \mathrm{~d}$ period in a greenhouse. The seeds were planted in the $1.5-2.0 \mathrm{~cm}$ depth of the surface soil in each pot. Pots were kept in a greenhouse under natural sunlight (19-25 ${ }^{\circ} \mathrm{C}, 10-12 \mathrm{~h}$ light) to imitate real-world conditions, and irri-
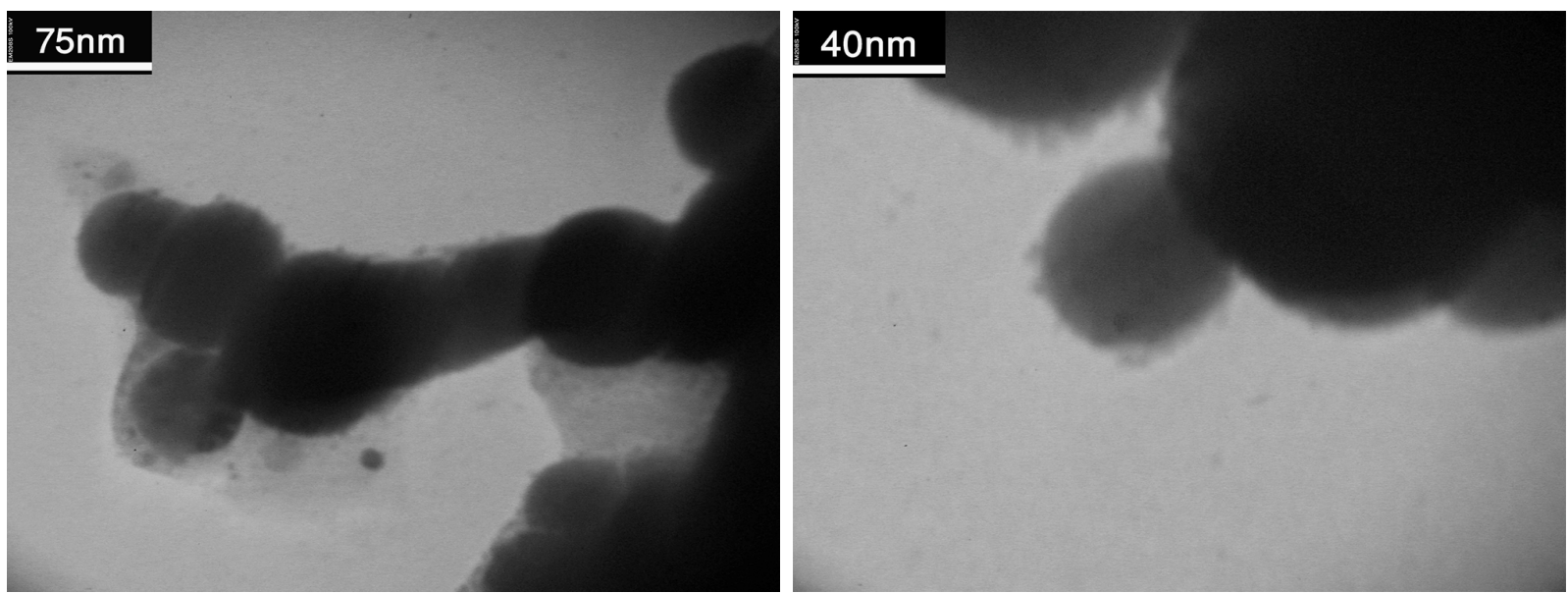

Fig. 1. TEM images of the synthesized nanoparticles of zero-valent iron. 
gated two or three times per week to $75 \%$ of the field capacity of the soil. Pot experiments were carried out in three replicates. Pots were monitored to assess seedling emergence rate in different treatments and grown plants were harvested after $60 \mathrm{~d}$, then the biomass and length of roots and shoots were measured. Plants were dried in an oven at $70^{\circ} \mathrm{C}$ for $48 \mathrm{~h}$ to obtain dry weight of the biomass. Phytoremediation effectiveness could be limited by various factors such as pot size and nutrient availability in the confined pots. Efficiency of phytoremediation is usually restricted by root depth in real-world conditions, but it is not the case in pot experiments, and plant root often reach the bottom of pots. However, confinement of pots restricts extension of roots in greenhouse studies. Number of seeds in each pot and their density is another limiting factor. Other factors such as soil properties and climate conditions can also affect phytoremediation effectiveness.

\subsection{Determination of Metals in Plant Organs}

After harvesting, plant roots and shoots were thoroughly rinsed with distilled water, dried at room temperature $\left(22-25^{\circ} \mathrm{C}\right)$, and then oven-dried at $60^{\circ} \mathrm{C}$ for $12 \mathrm{~h}$. The obtained samples were ground through a 200 mesh. Plant samples $(0.5 \mathrm{~g})$ digested in a digestion tube at a temperature of $100-230^{\circ} \mathrm{C}$ with $4.0 \mathrm{~mL} \mathrm{HNO}_{3}$ and 1.0

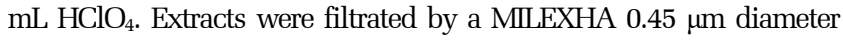
filter to obtain a clear solution, and then analyzed for the total concentration of $\mathrm{Pb}$ and $\mathrm{Fe}$ by flame atomic absorption spectroscopy (Perkin Elmer 700) [31, 32].

\subsection{Bio Concentration and Translocation Factors}

The bio concentration factor (BCF) is used to calculate the metal uptake capacity from soil to plant tissues. It can be measured for each plant part, such as roots and shoots. Translocation factor (TF) is also an important tool to assess the potential of a given plant for phytoremediation purposes. It is determined from the ratio of the concentration of an element in plant's shoots compared to that in the plant's roots. BCF and TF were calculated using the following equations [33]:

$$
\begin{gathered}
B C F=\frac{\text { Concentration of metal in roots }}{\text { Concentration of metal in test soil }} \\
T F=\frac{\text { Concentration of metal in shoots }}{\text { Concentration of metal in roots }}
\end{gathered}
$$

\subsection{Chlorophyll Content}

Fresh leaves materials were analyzed in dark condition to determine chlorophyll content in different treatments. Accurately weighted amount $(0.5 \mathrm{~g})$ of intact leaves were grinded thoroughly, $20 \mathrm{~mL}$ of $80 \%$ acetone was added. Milled mixture was then incubated at $4^{\circ} \mathrm{C}$ for $3 \mathrm{~h}$, and centrifuged for $5 \mathrm{~min}$ at 2,500 rpm to remove particulate matter. The supernatant was filtered and transferred into a $50 \mathrm{~mL}$ volumetric flask and the volume was made up to $50 \mathrm{~mL}$ by addition of $80 \%$ acetone. Chlorophyll content was measured by UV spectrophotometry at $645 \mathrm{~nm}$ and $663 \mathrm{~nm}$ [34]. The chlorophyll $a($ Chl a), chlorophyll $b(\mathrm{Chl} b)$, and chlorophyll $a+$ $b$ (total chlorophyll) contents were calculated using the following equations [35]:

$$
\begin{gathered}
\text { Chl } a=12.7 \times A 663-2.69 \times A 645 \\
\text { Chl } b=22.9 \times A 645-4.68 \times A 663 \\
\text { Chl }(\text { total })=8.02 \times A 663-20.21 \times A 645
\end{gathered}
$$

\subsection{Statistical Analysis}

All statistical analyses were performed using IBM SPSS Statistics 24. All results in this paper were presented as the mean with standard errors $(n=3)$. Significance of differences was determined using one-way analysis of variance (ANOVA), followed by least significant difference (LSD) test. Significance level was considered at $\mathrm{P}=0.05$.

\section{Results and Discussion}

\subsection{Plant growth}

\subsubsection{Germination of K. scoparia}

Seedling emergence of $K$. scoparia in different treatments was monitored during the experiment. Applying nZVI concentrations of up to $500 \mathrm{mg} / \mathrm{kg}$ to soil did not change germination rate compared to the control. However, nZVI with concentrations of 1,000 and $1,500 \mathrm{mg} / \mathrm{kg}$ significantly reduced $K$. scoparia germination (Fig. 2). Exposure of peanut seed to nZVI at low concentrations stimulated the germination and development of seeds, which was attributed to the internalization of nZVI by the plants [36]. In this study, delayed germination was also observed due to addition of 1,000 $\mathrm{mg} / \mathrm{kg}$ and 1,500 mg/kg nZVI. However, $K$. scoparia showed high tolerance to the presence of elevated levels of nZVI, such that the lowest germination rate only dropped to $85 \pm 5 \%$ in 1,500 $\mathrm{mg} / \mathrm{kg}$ nZVI treatment. The ability to adapt harsh conditions under environmental stress is an important factor for a plant to be opted for remediation purposes.

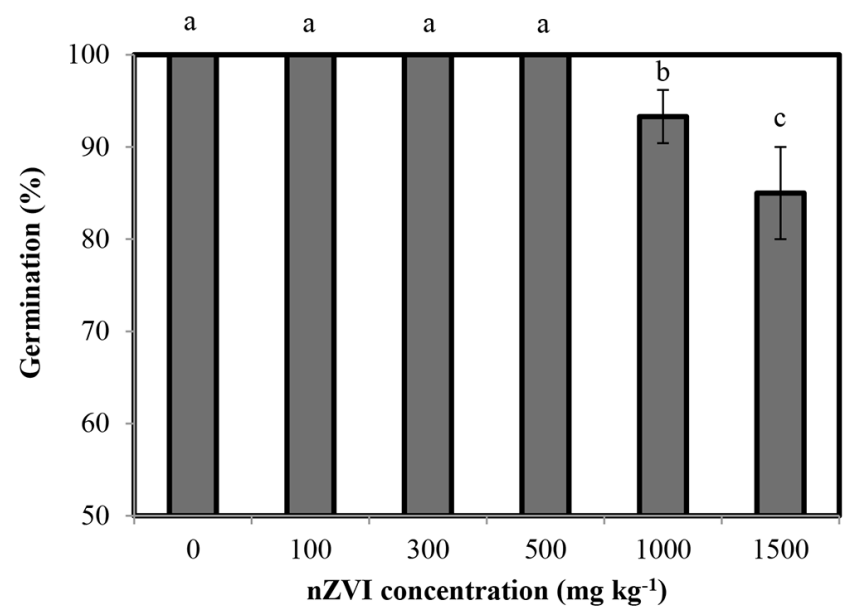

Fig. 2. Final seedling emergence of $K$. scoparia in Pb-contaminated soil treated with $\mathrm{nZVI}$. Error bars represent standard deviation of three replicates. Different letters represent significant differences between the treatments (mean $\pm S D ; n=3 ; p<0.05$ ). 


\subsubsection{Biomass of the roots and shoots of $\mathrm{K}$. scoparia}

Biomass and length of roots and shoots were determined after harvesting to assess the effects of nZVI treatment on plant growth. Fig. 3 (a) shows that applying nZVI to Pb-contaminated soil reduced root biomass of $K$. scoparia particularly at higher nZVI doses, while enhanced shoot biomass of plants in all treatments compared to the control. Decrease in roots biomass with the rising of nZVI levels was observed. The most significant increase in shoots biomass (54\%) was gained in $500 \mathrm{mg} / \mathrm{kg} \mathrm{nZVI}$ treatment, compared to the control (Fig. 3 (a)). Total plant biomass increased with the application of 100 to $500 \mathrm{mg} / \mathrm{kg} \mathrm{nZVI}$, while declining trend was achieved in treated soils with higher nZVI concentrations. The extent of plant growth promotion or inhibition in presence of nanoparticles in soil was suggested to be related to plant type as well as nanoparticles types and concentrations [37]. K. scoparia is a reasonably fast growing species that makes it suitable for phytoremediation purposes. Establishment of considerable biomass is a crucial factor affecting phytoremediation potential of plants [38]. The length of roots followed the same trend as root biomass in response to addition of nZVI to soil and declined with increasing nZVI concentrations (Fig. 3 (b)). The growth of $K$. scoparia in the test soil treated with $1,500 \mathrm{mg} / \mathrm{kg} \mathrm{nZVI}$ with the root length of $9 \pm 0.8 \mathrm{~cm}$ and shoot length of $13.9 \pm 0.3$ was significantly suppressed in comparison with the growth yielded in the control treatment. Preliminary tests showed that germination and growth of $K$ scoparia were not altered in presence of applied concentration of $\mathrm{Pb}$ in soil compare to the clean soil (control), and highest possible growth was achieved in the test soil. Moreover, pre-tests showed inhibitory effect of 2,000 and $3,000 \mathrm{mg} / \mathrm{kg} \mathrm{nZVI}$ on germination and growth of $K$. scoparia, which markedly inhibit seedling emergence and plant growth. Amplified phytotoxicity of heavy metals by addition of nZVI to soil has been reported [36]. Sensibility of root extension and biomass of $K$. scoparia to high concentrations of nZVI (mainly greater than $1,000 \mathrm{mg} / \mathrm{kg}$ ) was found in this study, whereas lower concentrations of applied nZVI mostly promoted plant growth in Pb-contaminated soil. To be brief, low concentrations of nZVI favored plant growth, while elevated concentrations of nZVI i.e. 1,000 and 1,500 mg/kg in soil posed inhibitory effects on growth of $K$ scoparia. In addition, leaves of the $K$. scoparia withered more rapidly after addition of higher doses of nZVI in Pb-contaminated soil.

\subsection{Phytoextraction of $\mathrm{Pb}$ from Soil}

Phytoextraction is known to be the main mechanism by which heavy metals are remediated in soil during the phytoremediation process [39]. In this study, application of nZVI-assisted phytoremediation of $\mathrm{Pb}$-contaminated soil was aimed to promote $\mathrm{Pb}$ uptake and translocation in $K$. scoparia or enhance immobilization of $\mathrm{Pb}$ in the rhizosphere of $K$ scoparia. Table 1 presents the distribution of $\mathrm{Pb}$ in plant roots and shoots in different treatments. Concentrations of $\mathrm{Pb}$ in roots of $K$. scoparia were 86.48, 112.52, 142.22, 90.42 and $60.2 \mathrm{mg} / \mathrm{kg}$ in treated soils with 100, 300, 500, 1,000, and 1,500 mg/kg nZVI, respectively, compared to $64.06 \mathrm{mg} / \mathrm{kg}$ of the control. Concentrations of $\mathrm{Pb}$ in roots and shoots of $K$ scoparia grown in presence of $500 \mathrm{mg} / \mathrm{kg} \mathrm{nZVI}$ were $142.22 \mathrm{mg} / \mathrm{kg}$ and $49.78 \mathrm{mg} / \mathrm{kg}$ with a significant increase of 1.22 and 1.68 times, respectively, compared to the control. The concentrations of $\mathrm{Pb}$ in roots and shoot of $K$. scoparia cultivated in treated soil with $1,500 \mathrm{mg} / \mathrm{kg}$ nZVI were $60.20 \mathrm{mg} / \mathrm{kg}$ and $18.06 \mathrm{mg} / \mathrm{kg}$, showing a slight decrease of $6.02 \%$ and $2.80 \%$, respectively, compared with the control treatment. $\mathrm{Pb}$ concentrations in the roots were higher than those in the shoots in all nZVI amended and unamended treatments, indicating that $K$. scoparia roots were the preferential $\mathrm{Pb}$ storage organ. Reduction in concentrations of $\mathrm{Pb}$ in roots of $K$ scoparia under the effect of high doses of nZVI could be related to the large specific surface area of nZVI and their high adsorption capacity, which might reduce availability of $\mathrm{Pb}$ for being uptaken by the plant roots [40]. Besides that, inhibitory effects of high doses of nZVI due to their toxicity could reduce $\mathrm{Pb}$ absorption by $K$. scoparia., as also suggested by other authors [41]. Accumulation of heavy metals in plants may induce oxidative
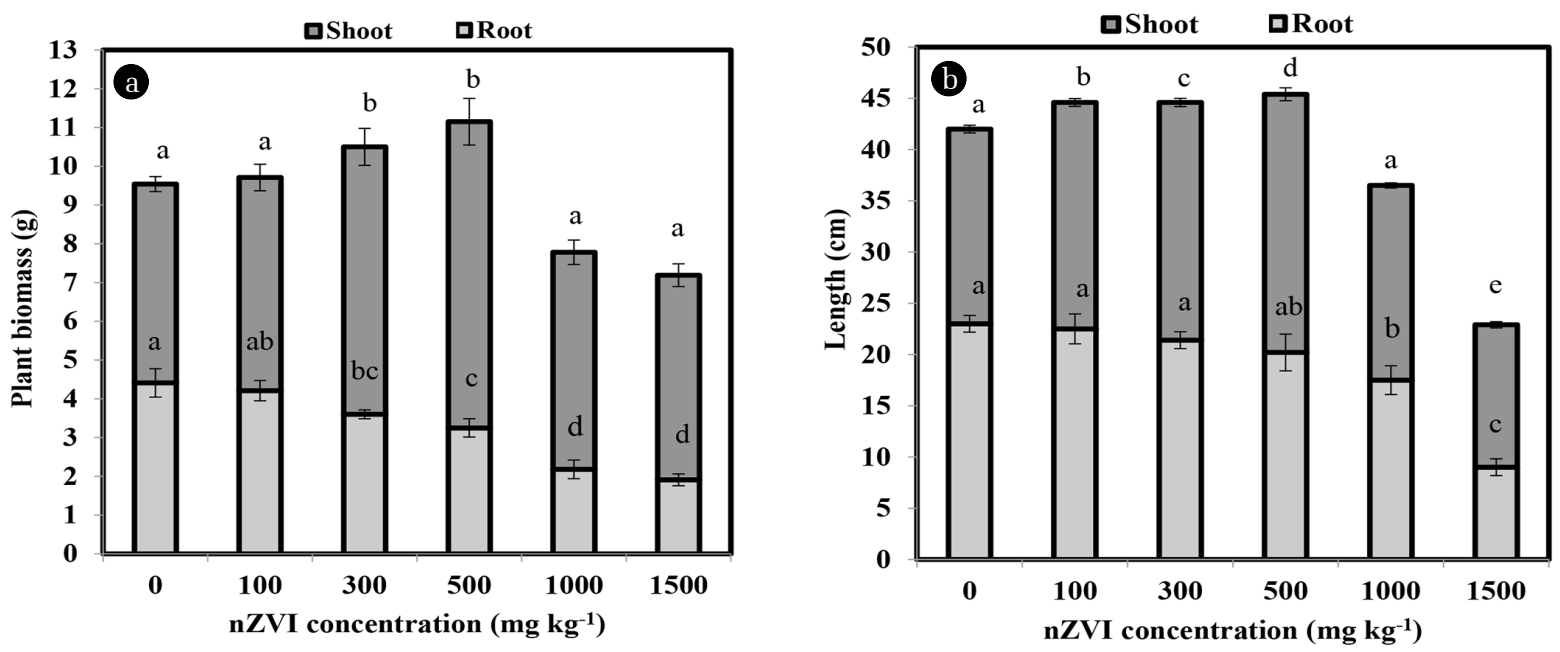

Fig. 3. The biomass (a) and length (b) of $K$. scoparia grown in different $n Z \mathrm{VI}$ treated soil samples at $60 \mathrm{~d}$. Error bars represent standard deviation of three replicates. Different letters represent significant differences in roots and shoots, respectively, between the treatments (mean \pm $\mathrm{SD} ; \mathrm{n}=3 ; \mathrm{p}<0.05$ ). 
Table 1. Distribution of $\mathrm{Pb}$ in Roots and Shoots of $K$. scoparia Grown in Pb-contaminated Soil in Different nZVI Treatments, Bio Concentration factors (BCF) and Translocation Factors (TF) of Pb in K. scoparia Grown in Different Soil Treatments after 60 d. Standard Deviations for Three Replicates Are Presented

\begin{tabular}{|c|c|c|c|c|}
\hline \multirow{2}{*}{$\begin{array}{l}\text { nZVI concentration } \\
(\mathrm{mg} / \mathrm{kg})\end{array}$} & \multicolumn{2}{|c|}{$\mathrm{Pb}$ concentration (mg/kg) } & \multicolumn{2}{|c|}{ Bio concentration and translocation factors } \\
\hline & Roots & Shoots & BCF & TF \\
\hline 0 & $64.06 \pm 1.00$ & $18.58 \pm 2.04$ & $0.88 \pm 0.02$ & $0.29 \pm 0.03$ \\
\hline 100 & $86.48 \pm 4.72$ & $26.81 \pm 2.40$ & $0.93 \pm 0.03$ & $0.31 \pm 0.02$ \\
\hline 300 & $112.52 \pm 5.20$ & $37.13 \pm 2.55$ & $1.12 \pm 0.08$ & $0.33 \pm 0.03$ \\
\hline 500 & $142.22 \pm 4.47$ & $49.78 \pm 5.87$ & $1.23 \pm 0.10$ & $0.35 \pm 0.04$ \\
\hline 1,000 & $90.42 \pm 4.63$ & $29.84 \pm 5.86$ & $1.08 \pm 0.03$ & $0.33 \pm 0.08$ \\
\hline 1,500 & $60.20 \pm 2.29$ & $18.06 \pm 1.23$ & $0.96 \pm 0.06$ & $0.30 \pm 0.01$ \\
\hline
\end{tabular}

stress due to the production and accumulation of reactive oxygen species (ROS). Low concentrations of nZVI were found to slightly relieve the oxidative stress in plants cultivated on heavy metal-contaminated soils, while elevated oxidative stress due to addition of high concentrations of nZVI has been reported in the literature [19]. Therefore, the high accumulation of both nZVI and Pb may induce significant oxidative stress and damage to antioxidant enzymes of plants. Heavy metals such as $\mathrm{Pb}$ may also cause chlorosis, alter water balance and nutrient assimilation, which ultimately pose plant death. In addition, heavy metals in soil may compete with some nutrients for absorption by roots, which results in a deficiency of nutrients such as iron for plant species. Direct interaction of heavy metals with sulfhydryl group (-SH) of functional proteins is also another mechanism in heavy metal contaminated soils, which may disrupts plant functions [7, 14, 36]. Lower doses of $\mathrm{nZVI}$ can overcome some of these problems such as iron deficiency in heavy metal-polluted soils. However, application of higher doses of nZVI might be harfmful to plant species. Nanoparticles can move along the plant pipeline upon their internalization by plants and the plant metabolism may be disturbed by excessive concentrations of nZVI [36].

The bio concentration factors (BCF) and translocation factors (TF) were calculated and presented in Table 1, to gain better understanding on the effects of nZVI-supported phytoremediation on absorption and translocation of $\mathrm{Pb}$ in $\mathrm{K}$ scoparia. Increase in BCF values was observed in $K$. scoparia grown in 100-1,500 mg/kg nZVI treated soil, compared with the control soil. In the present study, $\mathrm{BCF}$ values were greater than one for Pb-contaminated soil amended with 300,500 , and $1,000 \mathrm{mg} / \mathrm{kg}$ nZVI. This indicates the enhanced capability of $K$. scoparia to extract $\mathrm{Pb}$ from the soil in presence of the mentioned concentrations of nZVI. The greatest value of BCF (1.23) was achieved by addition of $500 \mathrm{mg} / \mathrm{kg} \mathrm{nZVI,} \mathrm{but} \mathrm{using}$ higher nZVI levels reduced BCF values.

Translocation of heavy metals from the roots to shoots and their accumulation in shoots is also an important index to evaluate the phytoextraction potential in plants. TF values were also slightly increased in presence of nZVI. TF values in nZVI treatments ranged from 0.3 to 0.35 for $\mathrm{Pb}$, with the highest $\mathrm{TF}$ value obtained for $500 \mathrm{mg} / \mathrm{kg} \mathrm{nZVI}$ treatment. The TF ratio was only slightly increased due to addition of nZVI; however, applying higher doses of nZVI showed inhibitory effects on translocation of $\mathrm{Pb}$ in $K$. scoparia. Higher nZVI concentrations could also adversely affect transfer of nutrients from roots to aerial parts [36]. In addition, oxygen deficiency in soil is a possible phenomenon due to the oxidation of nZVI, particularly in treatments received high concentrations of nZVI [42]. The concentration of Pb in the roots of $K$. scoparia was higher compared to aerial parts in all treatments, indicating low ability of $K$. scoparia to transfer $\mathrm{Pb}$ to aerial plant organs. The limited ability of plants to transfer heavy metals to the aerial parts of plants has also been reported in the literature as a result of blocking the root apex in plants due to the exposure to heavy metals [43]. Apoplastic barriers might develop near the root apex in plants grown under the stress of heavy metals, which reduce the translocation of sorbed metals from root to aerial parts [44].

Results showed that nZVI addition to soil, particularly at lower doses, increased the uptake and translocation of $\mathrm{Pb}$ for $K$. scoparia in comparison with non-nZVI treatment. Stomatal opening of plant leaves could be enhanced by nZVI, leading to increased $\mathrm{CO}_{2}$ uptake and photosynthesis [45]. Increased root length and biomass of $K$. scoparia at low doses of nZVI could help the plant to accumulate more $\mathrm{Pb}$ from soil as observed in this study; however, further investigation is required to gain better insight into probable mechanisms involved in this phenomenon. One probable reason is that, applying nZVI to soil may increase soil organic matter through root exudates of plants, which in turn promotes uptake and translocation of $K$. scoparia.

\subsection{Accumulation Capacity of $\mathrm{Pb}$}

$\mathrm{Pb}$ accumulation capacity of $K$. scoparia does not only depend on $\mathrm{Pb}$ concentration in plant organs, but also depends on plant dry biomass, which was calculated and illustrated in Fig. 4. The greatest total $\mathrm{Pb}$ accumulation capacity in $K$. scoparia was reached $857.18 \mu \mathrm{g}$ per pot, which was achieved in $500 \mathrm{mg} / \mathrm{kg} \mathrm{nZVI} \mathrm{treatment.}$ However, the least $\mathrm{Pb}$ accumulation capacity was calculated in $1,500 \mathrm{mg} / \mathrm{kg} \mathrm{nZVI}$ treatment $(210.80 \mu \mathrm{g}$ per pot), followed by 1,000 $\mathrm{mg} / \mathrm{kg}$ nZVI treatment (361.85 $\mu \mathrm{g}$ per pot). This indicates adverse effects of high concentrations of nZVI in soil on total $\mathrm{Pb}$ accumulation capacity of $K$ scoparia. $\mathrm{Pb}$ accumulation capacity in control treatment was slightly (4.18\%) higher than that of in $1,000 \mathrm{mg} / \mathrm{kg}$ nZVI treatment. Results indicated that addition of nZVI in low doses could effectively increase the accumulation capacity of $\mathrm{Pb}$ for the studied plant, which is in agreement with findings of $\mathrm{Hu}$ et al. [46] who found increased As accumulation capacity of wheat in graphene oxide amended sediments. In contrast, in another study, 


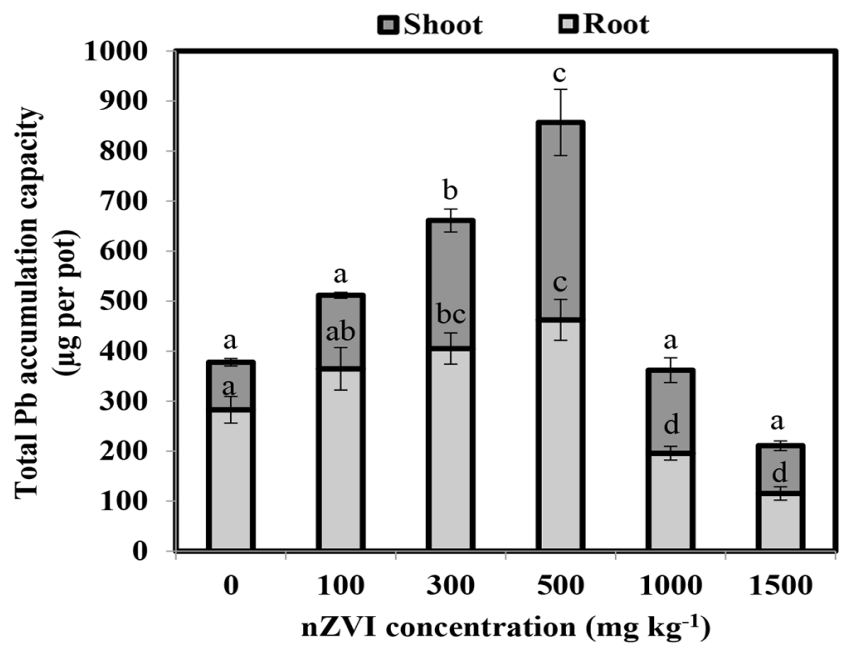

Fig. 4. The $\mathrm{Pb}$ accumulation capacity in roots and shoots of $K$. scoparia grown in different nZVI-containing soils at $60 \mathrm{~d}$. Error bars represent standard deviation of three replicates. Different letters represent significant differences in roots and shoots, respectively, between the treatments (mean $\pm \mathrm{SD} ; \mathrm{n}=3 ; \mathrm{p}<0.05$ ).

reduced upward translocation and accumulation of $\mathrm{Cr}(\mathrm{VI})$ in plant-soil system treated with biochar-stabilized nZVI was found [46]. Future application of nanomaterials in remediation works is inevitable because of their effective performance. Nanomaterials should only be used at optimal concentrations due to the fact that their excessive applications on different media such as soil may pose serious environmental hazards [47]. The environmental fate and toxicity of nanomaterials are critical issues in materials selection and design for soil remediation purposes. The knowledge about the environmental fate and toxicity of nanomaterials is still inadequate [48, 49]. Findings of this research revealed that applying proper doses of nZVI may be beneficial for plant growth with no adverse impact on plant growth parameters; while higher doses of nZVI adversely affected the plant growth. Therefore it is crucial to determine proper doses of nanomaterials for soil remediation works, as addressed in this study, to avoid excessive use of nanomaterials and prevent their associated environmental risks. In other word, for real-world applications of nanomaterials such as nZVI the first step is to implement a pilot study in order to identify optimum conditions such as minimum required doses of nanomaterials for the effective support of phytoremediation, which might be site-specific and affected by plant species, soil type, and pollutant type and concentrations [50]. Advances in preparation of more environmental-friendly nanomaterials can also promote nanomaterials applications in the future [51]. Based on the plant growth and accumulation capacity of $\mathrm{Pb}$ in $K$. scoparia, it is suggested that application of low to moderate concentrations of nZVI could be promising to assist phytoremediation of $\mathrm{Pb}$ in soil, with the best performance at nZVI concentration of $500 \mathrm{mg} / \mathrm{kg}$.

\subsection{Fe Accumulation and Translocation}

Iron is an essential micronutrient for plants growth and survival involved in cellular functions, such as DNA synthesis, nitrogen fixation and photosynthesis [52]. Concentrations of Fe in all harvested plants were determined in this research to assess the effect of nZVI-assisted phytoremediation of $\mathrm{Pb}$ on absorption of Fe. Table 2 indicates that the total Fe levels in roots were significantly higher than those in shoots, which may be attributed to the direct exposure of the $K$. scoparia roots to the nZVI in soil. Concentrations of Fe in roots increased with nZVI concentration to hit a plateau of $2,528.72 \mathrm{mg} / \mathrm{kg}$ in treated soil with $1,500 \mathrm{mg} / \mathrm{kg} \mathrm{nZVI}$, which was 2.71 times greater than the corresponding value in control treatment. In $100-500 \mathrm{mg} / \mathrm{kg} \mathrm{nZVI}$ treatments, the concentrations of $\mathrm{Fe}$ in shoots as well as TF values increased with the rising of nZVI. It suggests that low contents of nZVI could promote translocation of Fe in K. scoparia. Despite the increase in concentrations of Fe in the roots of $K$. scoparia, translocation factors of Fe declined in 1,000-1,500 mg/kg nZVI treatments. This implied that application of high concentrations of nZVI had inhibitory effects on translocation of Fe within the plant, which might be due to the plugging of the pathway of Fe from the root to the shoot by nZVI as also suggested in the literature [22]. This signifies application of low concentrations of nZVI to successfully assist phytoremediation of heavy metals in soil because when the pathway of metals from the roots to the shoots are blocked by excessive amounts of nZVI, target heavy metals could not transfer effectively from the roots to the shoots, therefore accumulation of heavy metals in shoots could be decreased, which was in agreement with the result of $\mathrm{Pb}$ accumulation in $\mathrm{K}$ scoparia. The highest total Fe accumulation capacity in $K$ scoparia was found to be $11,647.11 \mu \mathrm{g}$ per pot, which was also achieved in $500 \mathrm{mg} / \mathrm{kg}$ nZVI treatment. Fig. 5 illustrates

Table 2. Distribution of Fe in Roots and Shoots of K. scoparia Grown in Pb-Contaminated Soil in Different nZVI Treatments, Bio Concentration Factors (BCF) and Translocation Factors (TF) of Fe in K. scoparia Grown in Different Soil Treatments after 60 d. Standard Deviations for Three Replicates Are Presented

\begin{tabular}{|c|c|c|c|c|}
\hline \multirow{2}{*}{$\begin{array}{l}\text { nZVI concentration } \\
(\mathrm{mg} / \mathrm{kg})\end{array}$} & \multicolumn{2}{|c|}{ Fe concentration (mg/kg) } & \multicolumn{2}{|c|}{ Bio concentration and translocation factors of $\mathrm{Fe}$} \\
\hline & Roots & Shoots & BCF & TF \\
\hline 0 & $932.86 \pm 24.20$ & $326.50 \pm 32.77$ & $2.28 \pm 0.07$ & $0.35 \pm 0.04$ \\
\hline 100 & $1366.68 \pm 37.09$ & $505.67 \pm 61.97$ & $2.43 \pm 0.05$ & $0.37 \pm 0.05$ \\
\hline 300 & $1540.56 \pm 40.07$ & $647.04 \pm 34.85$ & $2.91 \pm 0.06$ & $0.42 \pm 0.01$ \\
\hline 500 & $1727.51 \pm 62.50$ & $760.10 \pm 81.12$ & $3.34 \pm 0.03$ & $0.44 \pm 0.06$ \\
\hline 1,000 & $2268.96 \pm 60.75$ & $839.52 \pm 40.25$ & $2.66 \pm 0.06$ & $0.37 \pm 0.02$ \\
\hline 1,500 & $2528.72 \pm 49.24$ & $783.90 \pm 53.19$ & $2.64 \pm 0.09$ & $0.31 \pm 0.02$ \\
\hline
\end{tabular}


that accumulation capacity of Fe in $K$. scoparia enhanced in all nZVI treatments compared to non-nZVI treatment. Table 2 indicates that the lower contents of nZVI significantly promoted Fe uptake and translocation, while higher contents of nZVI reduced uptake and translocation of $\mathrm{Fe}$ in $K$. scoparia. BCF and TF values of $\mathrm{Fe}$ in nZVI treatments ranged from 2.43 to 3.34 and 0.31 to 0.44 , respectively, with the highest values obtained in $500 \mathrm{mg} / \mathrm{kg} \mathrm{nZVI}$ treatment, which is in agreement with the corresponding tendency of $\mathrm{Pb}$. Overally, accumulation and translocation of Fe by $\mathrm{K}$. scoparia in the nZVI treated soil showed the same trend as $\mathrm{Pb}$.

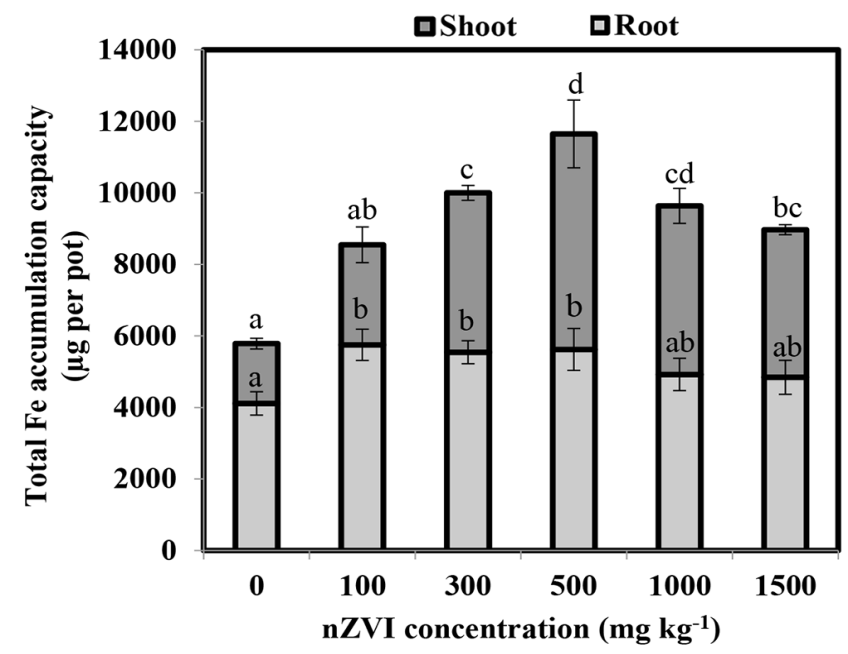

Fig. 5. The Fe accumulation capacity in roots and shoots of $K$. scoparia grown in different nZVI-containing soils at $60 \mathrm{~d}$. Error bars represent standard deviation of three replicates. Different letters represent significant differences in roots and shoots, respectively, between the treatments (mean $\pm \mathrm{SD} ; \mathrm{n}=3 ; \mathrm{p}<0.05$ ).

\subsection{The nZVI-Induced Photosynthesis Effect}

Fig. 6 shows that the accumulation of $\mathrm{nZVI}$ and $\mathrm{Pb}$ caused physiological changes in $K$. scoparia. Chl $a$ and Chl $b$ were used as the biomarkers of photosynthesis ability of $K$. scoparia in different treatments. Addition of low concentrations of nZVI $(100-500 \mathrm{mg} / \mathrm{kg})$ to the Pb-contaminated soil did not change Chl $a$ and Chl $b$ contents in this study. But Chl $a$, Chl $b$ and the total chlorophyll contents significantly declined at higher concentrations of nZVI (1,000-1,500 $\mathrm{mg} / \mathrm{kg}$ ). Decreasing of chlorophyll content at higher levels of nZVI could be caused by adverse impact of high doses of nZVI on the biochemical factors i.e. lipid peroxidation in photosynthesis membranes [53]. The ratio of $\mathrm{Chl} a / \mathrm{Chl} b$ could also be used as a useful indicator for environmental stress. $\mathrm{Chl} a / \mathrm{Chl} b$ ratio was slightly changed at low concentrations of nZVI compared with the control; however, $\mathrm{Chl} a / \mathrm{Chl} b$ ratio in presence of $1,500 \mathrm{mg} / \mathrm{kg}$ nZVI showed profound difference with the control (Fig. 6). Applying 1,500 mg/kg nZVI posed the greatest suppression rates for chlorophyll content of $K$. scoparia (22.58\%) compared to the control, which may be attributed to the damaged chloroplast internal organization [54]. It was concluded that high concentrations of nZVI induced negative effect on plant photosynthesis, which was in agreement with the results of $K$ scoparia biomass and length at higher doses of nZVI.

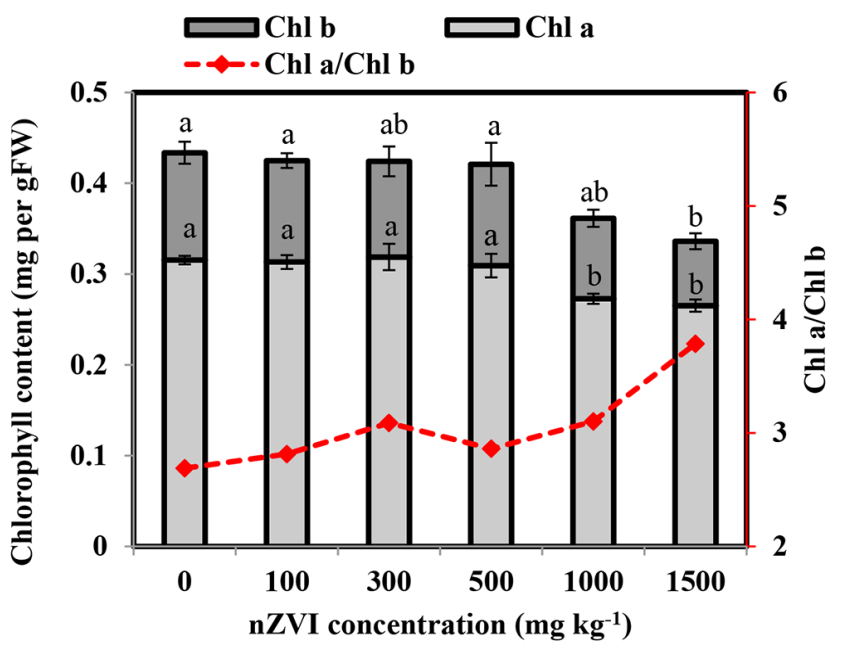

Fig. 6. Changes of the chlorophyll content of $K$. scoparia grown in different nZVI-containing soils at $60 \mathrm{~d}$. Error bars represent standard deviation of three replicates. Different letters represent significant differences in roots and shoots, respectively, between the treatments (mean $\pm \mathrm{SD} ; \mathrm{n}=3 ; \mathrm{p}<0.05$ ).

\section{Conclusions}

This study presented a promising novel technique by the integrated use of nanotechnology and phytoremediation in the remediation of $\mathrm{Pb}$ contaminated sites. Application of low to moderate concentrations of nZVI (100-500 mg/kg) enhanced $\mathrm{Pb}$ accumulation capacity in roots and shoots of $K$. scoparia, in comparison with the control treatment. In contrast, the higher levels of nZVI exhibited inhibitory impacts on plant growth, and therefore $\mathrm{Pb}$ remediation effectiveness. Leaf physiological structure was also adversely affected by addition of high concentrations of nZVI to soil. A slight decline was obsereved in Chl $a$ and Chl $b$ contents of $K$ scoparia in presence of up to $500 \mathrm{mg} / \mathrm{kg} \mathrm{nZVI}$ in soil, compared with the control, while significant negative effect of nZVI on plant photosynthesis was found at higher nZVI concentrations. Significantly higher accumulation of $\mathrm{Pb}$ in roots of $K$. scoparia compared to the shoots in all treatments suggested that phytostabilization could be the dominant mechanism in phytoremediation of $\mathrm{Pb}$ in both unamended and nZVI-amended soil. Low concentrations of nZVI effectively increased accumulation capacity of K. scoparia for $\mathrm{Pb}$ with plant growth promotion. Iron uptake by $K$ scoparia and its accumulation in the plant tissues exhibited similar trend as lead. Organo-metallic interactions as well as redox reactions may also play an important role in nanomaterials-assisted-phytoremediation which can be further investigated in future studies. Soil pH can also play a key role in the phytoavailability of heavy metals in presence of nanomaterials in soil, which is suggested for future researches. Engineering use of nanomaterials coupled with biological methods require significant cautions to be taken into account. In summary, the addition of low concentrations of nZVI could promisingly support $K$. $\mathrm{sco}^{-}$ paria growth and promote the uptake and translocation of $\mathrm{Pb}$ in plant. Stabilization of $\mathrm{Pb}$ in soil was also boosted by using 
low concentrations of nZVI, which demonstrated that combined use of nZVI and phytoremediation could be a promising approach to remediate $\mathrm{Pb}$-contaminated soils.

\section{Acknowledgment}

The authors would like to thank the University of Tehran for the financial support of this research.

\section{Author Contributions}

A.D.Z. (Assistant Professor) developed the theory and idea, carried out the experiments, performed and verified the analytic calculations and numerical simulations, wrote the manuscript. A.M.T. (Associate Professor) developed the theory and idea, carried out parts of the experiments, verified the analytic calculations, wrote the manuscript.

\section{References}

1. Rai PK, Lee SS, Zhang M, et al. Heavy metals in food crops: Health risks, fate, mechanisms, and management. Environ. Int. 2019;125:365-385.

2. Sharma A, Gupta AK, Ganguly R. Impact of open dumping of municipal solid waste on soil properties in mountainous region. J. Rock Mech. Geotech. Eng. 2018;10(4):725-739.

3. Ahmad SZN, Salleh WNW, Ismail AF, et al. Adsorptive removal of heavy metal ions using graphene-based nanomaterials: Toxicity, roles of functional groups and mechanisms. Chemosphere 2020:126008.

4. Jaishankar M, Tseten T, Anbalagan N, et al. Toxicity, mechanism and health effects of some heavy metals. Interdiscip. toxicol. 2014;7(2):60-72.

5. Song B, Xu P, Chen M, et al. Using nanomaterials to facilitate the phytoremediation of contaminated soil. Crit. Rev. Environ. Sci. Technol. 2019;49(9):791-824.

6. Abadin H, Taylor J, Buser MC, et al. Toxicological profile for lead: draft for public comment. 2019.

7. Shu X, Yin L, Zhang Q, et al. Effect of $\mathrm{Pb}$ toxicity on leaf growth, antioxidant enzyme activities, and photosynthesis in cuttings and seedlings of Jatropha curcas L. Environ. Sci. Pollut. Res. 2012;19(3):893-902.

8. Ehsan S, Ali S, Noureen S, et al. Citric acid assisted phytoremediation of cadmium by Brassica napus L. Ecotoxicol. Environ. Saf. 2014;106:164-172.

9. Pilon-Smits E. Phytoremediation. Annu. Rev. Plant Biol. 2005;56:15-39.

10. Singh O, Jain R. Phytoremediation of toxic aromatic pollutants from soil. Appl. Microbiol. Biotechnol. 2003;63(2):128-135.

11. Zand AD, Nabibidhendi G, Mehrdadi N, et al. Total Petroleum Hydrocarbon (TPHs) Dissipation through Rhizoremediation by Plant Species. Pol. J. Environ. Stud. 2010;19(1):115-122.

12. Wan X, Lei M, Chen T. Cost-benefit calculation of phytoremediation technology for heavy-metal-contaminated soil. Sci.
Total. Environ. 2016;563-564:796-802.

13. Ashraf S, Ali Q, Zahir ZA, et al. Phytoremediation: Environmentally sustainable way for reclamation of heavy metal polluted soils. Ecotoxicol. Environ. Saf. 2019;174:714-727.

14. Huang $\mathrm{C}$, Lai $\mathrm{C}, \mathrm{Xu} \mathrm{P}$, et al. Lead-induced oxidative stress and antioxidant response provide insight into the tolerance of Phanerochaete chrysosporium to lead exposure. Chemosphere. 2017;187:70-77.

15. Karami N, Clemente R, Moreno-Jiménez E, et al. Efficiency of green waste compost and biochar soil amendments for reducing lead and copper mobility and uptake to ryegrass. $J$. Hazard. Mater. 2011;191(1-3):41-48.

16. Saghi A, Rashed Mohassel MH, Parsa M, et al. Phytoremediation of lead-contaminated soil by Sinapis arvensis and Rapistrum rugosum. Int. J. Phytorem. 2016;4: 387-392.

17. Gil-Díaz M, Pinilla P, Alonso J, et al. Viability of a nanoremediation process in single or multi-metal (loid) contaminated soils. J. Hazard. Mater. 2017;321:812-819.

18. Diego B, Rubén F, Lorena W. Nanoremediation of As and metals polluted soils by means of graphene oxide nanoparticles. Sci. Rep. 2020;10:1896.

19. Mokarram-Kashtiban S, Hosseini SM, Kouchaksaraei MT, et al. The impact of nanoparticles zero-valent iron (nZVI) and rhizosphere microorganisms on the phytoremediation ability of white willow and its response. Environ. Sci. Pollut. Res. 2019;26(11):10776-10789.

20. Huang D, Qin X, Peng Z, et al. Nanoscale zero-valent iron assisted phytoremediation of $\mathrm{Pb}$ in sediment: Impacts on metal accumulation and antioxidative system of Lolium perenne. Ecotoxicol. Environ. Saf. 2018;153:229-237.

21. Brasili E, Bavasso I, Petruccelli V, et al. Remediation of hexavalent chromium contaminated water through zero-valent iron nanoparticles and effects on tomato plant growth performance. Sci. Rep. 2020;10(1):1-11.

22. Ma X, Gurung A, Deng Y. Phytotoxicity and uptake of nanoscale zero-valent iron (nZVI) by two plant species. Sci. Total Environ. 2013;443:844-849.

23. Wang J, Fang Z, Cheng W, et al. Higher concentrations of nanoscale zero-valent iron (nZVI) in soil induced rice chlorosis due to inhibited active iron transportation. Environ. Pollut. 2016;210:338-345.

24. Kim JH, Lee Y, Kim EJ, et al. Exposure of iron nanoparticles to Arabidopsis thaliana enhances root elongation by triggering cell wall loosening. Environ. Sci. Technol. 2014;48(6):3477-3485.

25. Kumpiene J, Ore S, Renella G, et al. Assessment of zerovalent iron for stabilization of chromium, copper, and arsenic in soil. Environ. Pollut. 2006;144(1):62-69.

26. Burt R. Kellogg soil survey laboratory methods manual. United States Department of Agriculture, Natural Resources Conservation Service, National Soil Survey Center: Kellogg Soil Survey Laboratory Press; 2014.

27. Dewis J, Freitas F. Physical and chemical methods of soil and water analysis. FAO Soils Bulletin, New Delhi: Oxford and IBH Publishing CO; 1984.

28. Wang Y, Fang Z, Kang Y, et al. Immobilization and phytotoxicity of chromium in contaminated soil remediated by CMC-stabilized nZVI. J. Hazard. Mater. 2014;275:230-237. 
29. Papazoglou EG, Fernando AL. Preliminary studies on the growth, tolerance and phytoremediation ability of sugarbeet (Beta vulgaris L.) grown on heavy metal contaminated soil. Ind. Crop Prod. 2017;107:463-471

30. Walkley A, Black IA. An examination of the Degtjareff method for determining soil organic matter, and a proposed modification of the chromic acid titration method. Soil. Sci. 1934;37(1):29-38.

31. Shirdam R, Zand AD, Nabi Bidhendi G, et al. Removal of total petroleum hydrocarbons (TPHs) from oil-polluted soil in Iran. Iran. J. Chem. Chem. Eng. 2009;28 (4):105-113.

32. Huang Y, Tan K, Tang Q, et al. Removal of As (III) and As (V) from drinking water by nanoscale zero-valent iron. In: International Conference on Challenges in Environmental Science and Computer Engineering; 6-7 March 2010; Wuhan. p. 111-114.

33. Wannaz ED, Carreras HA, Abril GA, et al. Maximum values of $\mathrm{Ni} 2+, \mathrm{Cu} 2+, \mathrm{Pb} 2+$ and $\mathrm{Zn} 2+$ in the biomonitor Tillandsia capillaris (Bromeliaceae): Relationship with cell membrane damage. Environ. Exp. Bot. 2011;74:296-301.

34. Fang R. Application of atomic absorption spectroscopy in sanitary test. Beijing: Beijing University Press; 1991. p. 148-158.

35. Embrandiri A, Rupani P, Shahadat M, et al. The phytoextraction potential of selected vegetable plants from soil amended with oil palm decanter cake. Int. J. Recycl. Org. Waste Agri. 2017;6(1): $37-45$.

36. Wellburn R. The spectral determination of chlorophylls a and $\mathrm{b}$, as well as total carotenoids, using various solvents with spectrophotometers of different resolution. J. Plant Physiol. 1994;144(3):307-313.

37. Arnon DI. Copper enzymes in isolated chloroplasts. Polyphenoloxidase in Beta vulgaris. Plant Physiol. 1949;24(1):1.

38. Huang R, Dong M, Mao P, et al. Evaluation of phytoremediation potential of five $\mathrm{Cd}$ (hyper) accumulators in two Cd contaminated soils. Sci. Total Environ. 2020:137581.

39. Yoon H, Kang Y-G, Chang Y-S, et al. Effects of Zerovalent Iron Nanoparticles on Photosynthesis and Biochemical Adaptation of Soil-Grown Arabidopsis thaliana. Nanomaterials 2019; 9(11):1543

40. Chen Z-J, Tian Y-H, Zhang Y, et al. Effects of root organic exudates on rhizosphere microbes and nutrient removal in the constructed wetlands. Ecol. Eng. 2016;92:243-250.

41. Bhargava A, Carmona FF, Bhargava M, et al. Approaches for enhanced phytoextraction of heavy metals. J. Environ. Manage. 2012;105:103-120.

42. Xue W, Huang D, Zeng G, et al. Nanoscale zero-valent iron coated with rhamnolipid as an effective stabilizer for immobilization of $\mathrm{Cd}$ and $\mathrm{Pb}$ in river sediments. J. Hazard. Mater. 2018;341:381-389.

43. Cao J, Feng Y, Lin X, et al. Iron oxide magnetic nanoparticles deteriorate the mutual interaction between arbuscular mycorrhizal fungi and plant. J. Soils Sed. 2017;17(3):841-851.

44. El-Temsah YS, Sevcu A, Bobcikova K, et al. DDT degradation efficiency and ecotoxicological effects of two types of nano-sized zero-valent iron (nZVI) in water and soil. Chemosphere 2016;144:2221-2228.

45. Wang S, Shi X, Sun H, et al. Variations in metal tolerance and accumulation in three hydroponically cultivated varieties of Salix integra treated with lead. PloS One. 2014;9(9).

46. Vatehová Z, Kollárová K, Zelko I, et al. Interaction of silicon and cadmium in Brassica juncea and Brassica napus. Biologia 2012;67(3):498-504.

47. Jiang D, Zeng G, Huang D, et al. Remediation of contaminated soils by enhanced nanoscale zero valent iron. Environ. Res. 2018;163:217-227.

48. Areecheewakul S, Adamcakova-Dodd A, Givens BE, et al. Toxicity assessment of metal oxide nanomaterials using in vitro screening and murine acute inhalation studies. NanoImpact 2020:100214.

49. Zhu Y, Xu F, Liu Q, et al. Nanomaterials and plants: Positive effects, toxicity and the remediation of metal and metalloid pollution in soil. Sci. Total Environ. 2019;662:414-421.

50. Yirsaw BD, Megharaj M, Chen Z, et al. Environmental application and ecological significance of nano-zero valent iron. $J$. Environ. Sci. 2016;44:88-98.

51. Peng Z, Liu X, Zhang W, et al. Advances in the application, toxicity and degradation of carbon nanomaterials in environment: A review. Environ. Int. 2020;134:105298.

52. Kim JH, Oh Y, Yoon $\mathrm{H}$, et al. Iron nanoparticle-induced activation of plasma membrane $\mathrm{H}+$-ATPase promotes stomatal opening in Arabidopsis thaliana. Environ. Sci. Technol. 2015;49(2): 1113-1119.

53. Hu B, Liang D, Liu J, et al. Transformation of heavy metal fractions on soil urease and nitrate reductase activities in copper and selenium co-contaminated soil. Ecotoxicol. Environ. Saf. 2014;110:41-48.

54. Su H, Fang Z, Tsang PE, et al. Stabilisation of nanoscale zero-valent iron with biochar for enhanced transport and in-situ remediation of hexavalent chromium in soil. Environ. Pollut. 2016;214:94-100. 